\title{
SUSTAINABLE DEVELOPMENT IN SLOVAK EDUCATIONAL CONTEXT
}

\author{
Eva Svitacova - Elena Kovacikova
}

\section{doi: 10.18355/PG.2016.5.2.271-282}

\begin{abstract}
Based on the fact that education is a presupposition of sustainable development, the main aim of the paper is to point at the attempts to implement the topic of sustainable development within the educational system in Slovakia. Firstly, it defines the term education for sustainable development and its implementation at particular school levels especially at economic faculties. After that, the paper describes two qualitative studies carried out under the Cultural and Educational Grant Agency of the Ministry of Education, Research and Sport of the Slovak Republic (KEGA). The first research points out the fact that sustainable development is covered by main topics discussed in new educational approaches such as global education with the aim to prepare their graduates to be global citizens. The second research focuses at the preparation of university teachers for education in sustainable development through the courses of university pedagogy which are offered to the teachers at economic and technical faculties in Slovakia. The aim of these courses is to form global competences of university teachers and enforce their responsibility for development of the society and sustainable development in the world in which future graduates live as global citizens.
\end{abstract}

\section{Key words}

sustainable development, education for sustainable development, economic universities, university pedagogues, global education, global citizenship

\section{Introduction}

Globalization process which goes hand in hand with technological development substantially changes the nature of university education. Internationalization of the education is connected with the process of globalization which represents an inevitable condition of long-term competitiveness of colleges and universities on national, European and worldwide level. Internationalization of education shall widen knowledge and cultural view of future graduates with the knowledge needed in respect for social and political realia of European countries and all over the world. These tasks undoubtedly set their demands on university teachers and thus, one of the presuppositions of university internationalization is a conscientious preparation of pedagogues which should be focused not only on formation of professional competences. Regarding the fact that they should be able to realize their practice at universities professionally, their preparation should be focused also on acquirement of other competences. These help them evaluate and interpret the character, procedure and also consequences of social phenomena and processes in the educational process. They also enable them clarify the need to direct actions in the way that they 
will be in concordance with sustainable development, with its aim to provide a quality life for the humankind, current and future generations. However, university teachers should be firstly aware of sustainable development and consequently, they should transmit this requirement into the educational process at colleges and universities.

\section{Education as a prerequisite for sustainable development}

The concept of sustainable development has been discussed and formulated recently, whereby gradually it has become clearer that the education is a key to sustainability. The aim of sustainable development is to provide the quality life for people and the whole humankind for today and future generations. The term "sustainable development appeared in the seventies years mainly in connection with the knowledge that any incontrollable growth (of population, production, consumption, pollution, etc.) cannot be sustainable within environment of limited sources. The most popular definition of the sustainable definition is offered by the Brundtland Report in 1987 which defines sustainable development as development which meets the needs of current generations without compromising the ability of future generations to meet their own needs (UNECE, 2005).

As the aim of sustainable development is a quality life for current and future generations, it is necessary for young generation to cope with it. In such connection Education for Sustainable Development (ESD) highlights the importance of critical thinking, increase of information and therefore enforcement of individuals, groups, communities and organizations and countries to make their own decisions and choices in favour of sustainable development.

On $25^{\text {th }}$ September 2015, the countries adopted some of the aims of sustainable development which were to protect the planet, end poverty and guarantee prosperity for everyone. A major progress has been made within the access to education at all levels and increase in a number of people enrolled in schools, particularly for girls and women. Thus, basic literacy skills have improved; however, still great efforts are necessary to make even bigger steps in order to achieve universal education goals (UN-DESA, 2015). Education for Sustainable Development (ESD) is an initiative dating back to the early nineties. The policy statements at the beginning referred to ESD as together bringing development and environment education in the UK, as well as in other industrialized counties. However, the environmental agenda tended to dominate. Since 1997 the UK authorities promoted ESD particularly within schools (Bourn, 2008).

Education for sustainability is about knowledge of development, skills, understanding and values. It also considers participation in decisions making process in the way we act individually or collectively, on a local or global level. Thus, the quality of life will be improved without destructing the future planet (DETR, 1998). This definition of education towards sustainable development corresponds with the education of a global citizen. As for Israel a global citizen is someone who identifies with being part of an emerging 
world community and whose actions contribute to building this community's values and practices (Israel, 2013).

\section{Education for Sustainability at Particular School Levels}

Pupils at elementary schools indirectly come across SD, however, the term "sustainable development" defined here is a unity and harmony of three pillars - economic, social and ecological, or institutions connected with it. The students get to know it also later in the secondary or tertiary level of education. In the lower levels of education the focus is put mainly on formation of environmental awareness in the field of nature and environment protection. Institutions providing secondary and tertiary education focus on comprehension of essential transfer towards sustainable development of the society.

In July 2014, at the meeting of representatives from the Ministries of environment and education, the United Nations Economic Commission for Europe (UNECE) developed the strategy on education for sustainable development, which should enable introduction and leading education for sustainable development (ESD) within the region of UNECE. Its aim is to support the UNECE members in development and implementation of education into formal systems of education, into all the subjects and also informal and after school curricula. It also states that university education shall significantly contribute towards development of necessary competences and knowledge acquirement (UNECE, 2009).

The task of education for sustainability is to develop and strengthen abilities of individuals, communities, organizations and countries in order to make their own decisions and choices in favour of sustainable development. In connection with the higher education it can be agreed that "in our view the greatest contribution higher education has to make to sustainable development is by enabling students to develop new values, skills and knowledge." (HEFCE, 2005: 20)

The Higher Education Sustainability Initiative (HESI) was created as a partnership of UN entities (UNESCO, UN-DESA, UNEP, Global Compact, and UNU) in the run-up to the United Nations Conference on Sustainable Development (Rio+20). Almost 300 universities from around the world are the members (Higher Education Sustainability Initiative).

The United Nations Environment Programme, or UNEP, created the Global Universities Partnership on Environment for Sustainability - GUPES and it is a network of 370 universities across the world to implement environment and sustainability practices into the curricula. Within the challenges are included the following: "the lack of a coordinated approach at all the levels of the institution to implement the necessary changes; insufficient staff development activities to empower staff to transform curricula and pedagogy towards a sustainable development perspective; and the persistence of disciplinary boundaries that inhibit the potential to address complex sustainable development issues"(Mohamedbhai, 2015: 45).

Education for Sustainable Development (ESD) can be considered a part of Global Citizenship Education (GCE)as it is focused on preparation of active citizens both locally and globally, who are able to think locally and globally, 
able to resolve global challenges and ultimately become proactive contributors to a more fair, peaceful, tolerant, inclusive, secure and sustainable world. Global Citizenship Education (GCE) is a framing paradigm which summarizes how education can develop the knowledge, skills, values and attitudes which learners need for securing a world which is more just, peaceful, tolerant, inclusive, secure and sustainable (UNESCO, 2014: 9). Global citizens should overtake the global responsibility and realize connections between their lives and people, places or problems all over the world. Education towards global citizenship has a multidimensional character and its aim is to acquire the feeling of belonging towards global citizenship, adequately learn global challenges or problems and risks in a new global environment and settle for sustainable development. This also means that incontrollable growth of population, production, consumption, pollution is unsustainable within environment of limited sources. This conscience of global citizens should be formed in educational process at all levels of schools.

Sustainable development (social, environmental and economic integration precautionary principles) belongs among the aspects which contribute to development of global citizens in higher education. It takes part in formation of values, attitudes, skills of global citizen (Bourn, n.d.).

\section{Education for Sustainability at Economic Universities}

The key task of education on sustainable development cannot be doubted.

The task of educational institutions, to which economic faculties belong, is to prepare graduates for the practice which is provided not by national but also global economic structures, multinational corporations or international financial institutions. "The attention of future economists is often focused on economic growth, with non-economics-related values pushed into the background. To correct this the requirement for socially responsible behaviour should be implemented into a number of topics in the educational process at economic faculties.“ (Svitačová et. Mravcova, 2014: 47).

Education at economic faculties and universities must aim towards considering economic activities within a wider system of social and ecological relations. This understanding is seen in a model "triple bottom line" or "3P - People, Planet, Profit" provided by John Elkington, the founder of British consultancy service called Sustainability. He pointed at the fact that societies must be prepared for the three totally different levels. One of them is a traditional rate of social profit "bottom line" - profit and loss. The second "bottom line" is a line connected with the costs for people in a business within the whole time of their action. The third "bottom line" focuses on environmental responsibility towards the natural environment (The Economist, 2009). An optimal and balanced relation among these levels is provided to economic subjects by sustainable development.

An important global challenge for economic universities in Slovakia is to educate young professionals for global economy so that each of them realizes the fact that global economy apart from economic prosperity must correspond 
with other values (humanity, tolerance, human rights, environment, etc.). Without them it is impossible to provide the sustainable development on the Earth. Foreign language preparation and cultural diversity awareness is also a part of the curricula at economic and technical faculties. Slovak experts (Horvathova, 2013; Kohutova, 2016; Mala, 2009; Reid, 2013, Vesela, 2012) on language preparation and building culture awareness provide research and write papers on development of language systems, skills and culture.

Education for sustainability at economic universities should stem from interpretation of the conflict between economy and environment, or nature which is apart from the conflict economy and man the second most serious conflict in a new economic and social environment. This conflict reached critical rate in a relation of economically more developed countries of the global North versus the countries of the global South as well as in several economically developed countries (Sikula, 2009). It is connected with an increase in utilizing natural sources regardless ecological costs. The motif of constantly increasing burden of the nature is to maximize man's well-being. Explication of the conflict represents an outcome for understanding the aim of sustainable development which is the quality life for the humankind, for current and future generation and furthermore, to understand the core of SD which is the connection of sustainability and development.

An important prerequisite for implementation of SD into activities of economic subjects is to realize the conflict between economic and ecological functions of the nature. For some economists there are attempts to show results regardless the natural sources and costs for removal environmental damages. Sustainable development presumes consciousness that the lifegiving function of the nature is damaged in such a way that survival of life on the planet is threatened. Economic functions of the nature (nature - storage of natural sources and waste assimilator of human activities) get into the conflicts with its ecological functions (the sum of natural estates and beauties). Later on, it is important to introduce SD as a long-term and global perspective which represents current integration of four components - aims which should be reached. In particular, these are social progress, effective protection of environment, responsible use of natural sources and keeping high and stable level of economic growth).

\section{Implementation of SD into Curriculum of the Slovak Economic Faculty}

The above mentioned educational approaches represent attempts to reach universal responsibility of not only for sustainability of life in the space - in the horizontal direction, but also the responsibility for human survival. These initiatives correspond with the Call of EU Council to provide high-quality curriculum and apply teaching methods which make provision for international dimension (EU Council, 2010, p.7). The above mentioned educational approaches pay attention to several global and development topics and they help students at economic faculties acquire necessary knowledge on situations in a new global environment and at the same time, gain responsibility for development and run of the society and sustainable development in the world in which they should act as global citizens. It was also confirmed by the research called Implementation of global development 
education into educational process at economic faculties (Svitacova, 2011). This research focused on implementation of global and development topics into curriculum of economic faculties with the help of new educational approach - a global development education. It was supported by the Cultural and Educational Grant Agency of the Ministry of Education, Science, Research and Sport of the Slovak Republic (KEGA). It pointed out the fact that a new educational approach - global development education enables more systematic implementation of global development topics into curricula of future economists. Thus, their responsibility for realized aims and the task is to strengthen and also bear responsibility for economic, political, social and cultural development of the world, also for sustainability of environment in a local and global level.

The global economy brings the phenomena which complicate the positive development of humanity in the planet. The main topics come from the National Strategy for global education 2012-2016 such as Sustainable development, Environment with regards to global aspects (climate changes, waste, environmental migration of air, soil, and natural sources, alternative energy sources (National Strategy for Global Education 2012-2016).

Project partners were university teachers of the Faculty of Economics and Management at the Slovak University of Agriculture in Nitra and they focused on other global problems of environmental nature whereby they pointed at the limits and negatives of economic growth, for possibilities to solve problems with energies, global contributions of energetic use of biomass, or technology development in the times of globalization. Moreover, they focused on social problems in the globalized world, compared economic development in developed and less developed countries or they called for requirement of societal responsibility in doing business in a new global environment. The teachers planned and tried using the above mentioned topics in their courses and thus implemented them into the curricula of economic faculties. The aim of implementation into educational process at economic universities proved the importance of making students understand that in concordance with SD it is required to reach such an economic growth which is socially fair and at the same time environmentally sustainable. In the process of education it is important to raise their responsibility for decreasing unpleasant effects on environment in the process of the whole life cycle. It was also stressed that in economic activities the attention must be paid to all the values which are important for lives of people, societies, and cultures, and in the wider context not only in the home or neighbouring countries. Thus, education should be focused on formation of all the levels of human knowledge (historic, cultural, social, environmental and legal) as they influence thinking and actions of a man (including the relation to the environment).

The KEGA research also pointed at the fact that particular faculties and universities should pay more attention to the preparation of the teachers who would be able to implement global and development topics into the educational process. They should be also able to teach the subjects such as Global development education, Development education or Development 
studies. This task is also about Sustainable development, which calls for the attention at economic faculties.

\section{Sustainable Development in the Preparation of Teachers at Economic Faculties}

Current teachers are perceived not only as mediators of important knowledge but also mediators of social values, attitudes and patterns of behaviour. They also take part in formation of pupils' or students' awareness not only at primary level but also at universities. Therefore, it is inevitable to pay special attention to their education.

University teachers might be considered as global teachers. This pays also for university teachers at economic universities and faculties because their task is to prepare highly qualified human resources in a new global economic and social environment. The global citizenship presumes bearing responsibilities for the world status, thus the responsibility for sustainable development is also connected with it. Education providers 'must operate in a more environmentally responsible way' and teach sustainable development, giving learners 'the opportunities and inspiration to think about and really appreciate their role as world citizens (DfES, 2003).

The need to educate teachers in the field of education in sustainable development (ESD) stems from several documents of international and national importance. As for example, according to the UN Decade of Education for Sustainable Development 2005-2014 one of the main goals is to strengthen teachers' education and their reorientation for sustainable development. Similarly, the UNECE Strategy on Education for Sustainable Development (2005) says that for providing successful education on SD an appropriate essential preparation and requalification of teachers as well as teaching experience exchange is extremely important.

The research KEGA No. 026SPU-4/2013 Conceptual modernization of content and methodological support of the Course of university pedagogy for teachers of technical universities (Seben, Zat'kova, 2013) aimed at the need to assess the content reconstruction of the study plan of the course and innovate it in order to involve the education on sustainable development.

One of the aims was to reconstruct the Course of University Pedagogy for teachers of technical and economic universities so that they would be able to provide a quality preparation of the students at technical faculties for the practice in a modern interconnected world. Acquirement of knowledge and competences belong to education on SD (UNECE, 2005). Project members were the Slovak University of Agriculture in Nitra and Trnava University in Trnava. They paid their attention to formation of global competences of university teachers which are considered to be the key competences. OECD Education Ministers reckon that "sustainable development and social cohesion depend critically on the competencies of all of our population with competencies understood to cover knowledge, skills, attitudes and values." (OECD, 2003: 4).

The partial aims of the projects were as follows:

- Development of electronic textbook comprising the topics of sustainable development; 
- Analysis of educational needs and motivation of university teachers in the field of their lifelong learning education;

- Development of a scientific monograph comprising the research papers of the project partners.

The outcome of the project confirmed the need to discuss the topics about sustainable development with the teachers to be so that the global competences help the teachers transfer their knowledge to university students and prepare them for meeting demanding tasks in different institutions in a new global environment. Their environmental responsibility and belief in a value of environment and all living forms on the Earth are strengthened. The research outcomes provided an implementation of sustainable development topics into the teacher training course for future pedagogues at the Faculty of Economy, Slovak University of Agriculture in Nitra.

\section{Recommendation on teacher training for ESD in Slovakia}

Education for sustainable development by teachers at all levels of schools firstly presumes its implementation into educational programs at faculties and universities of education. It says that "Education providers must operate in a more environmentally responsible way and teach sustainable development, giving learners the opportunities and inspiration to think about and really appreciate their role as world citizens'"(DfES, 2003).

Teachers of elementary and secondary schools in Slovakia are offered to take accredited education called: Ecological Footprint - Education on Sustainable Development. It is an effective educational method, a training manual for teachers with the aim to provide teachers with the problems of SD in a more understandable way. Education on sustainable development is also carried out through the forms of continual education or via Methodological days for teachers (SEA, 2015). Their aim is to develop qualification of pedagogical employees in the field of education on sustainable development.

Education for university teachers' in Slovakia is provided by several faculties of education offering the courses of university pedagogy but also different lectures and workshops with the aim to provide quality education for their graduates and form their profile pursuant to current requirements on the labour market in a new global environment. Some of them are focused on provision of education via ecological and environmental topics connected with their professional focus. However, this does not guarantee that they can realize a quality preparation of the students for sustainable development.

Regarding the university teacher preparation for SD, apart from faculties or universities of education, other universities should prepare the teachers with the help of courses of university pedagogy. In the Slovak scientific environment, the course of university pedagogy is defined as a pedagogical discipline focusing on educational processes and phenomena at tertiary level of education.

Mainly technical and economic colleges and universities offer to their teachers courses of university pedagogy (e.g. The course of university pedagogy for teachers - engineers at the Slovak Technical University in 
Bratislava, the Course of university pedagogy organized by the Centre of pedagogy and psychology at the Slovak University of Agriculture in Nitra, the Course of university pedagogy organized by the Centre for lifelong learning programs at Technical University in Zvolen and Department of pedagogy for engineers of the Technical University) with an attempt to upgrade professional education of university teachers mainly from the fields of educational sciences and form their pedagogical competences. The courses aim to show new educational approaches, forms of education developing actual societal needs.

\section{Conclusion}

We can agree with Bourn that "in many cases the obstacles to securing progress within society in sustainable development are the pressures of global economic forces" (Bourn, 2005, p.13).

Due to this reason, education at other schools, mainly at economic universities and faculties should go hand in hand with the trend of internationalization. Education on sustainable development is a part of it. However, the aims of ESD should focus on acquiring knowledge, formation of attitudes, values and development of intellect at all levels of schooling. It should develop and strengthen abilities of individuals, groups, communities, organizations and countries to carry out their decisions and choices in favour of sustainable development. Particularly, the graduates of economic universities should be aware of making the world more prosperous and also more secure and healthy. Their task is to increase quality of life in a new globalizing world which offers them their self-realization and development. On the other hand, they should know that there are several threats and dangers including the environmental ones. Sustainable development should be implemented appropriately into educational process of future economists. It is also the aim of the Global Citizenship Education (GCE). Currently, there is a trend of Education for Sustainable Development and Global Citizenship (ESDGC), which represents the links between society, economy and environment and between our own lives and those of people all over the world, the needs and rights of both present and future generations, the relationships between power, resources and human rights, the local and global implications of everything we do and the actions that individuals and organisations can take in response to local and global issues (ESDGC, 2008). Regarding the implementation of sustainable development into university education we cannot rely only on implementation of the topic into existing courses offered at economic faculties. It is necessary to implement more intensively new subjects - Development education or Development studies into study programs. Future economists can thus maintain and develop not only economic values but also other values important for human life in a wider context such as the home and neighbouring countries. Meeting the requirement stated in the UNECE Strategy for sustainable development, for contribution of university education towards ESD by development of particular knowledge and competences also presumes paying more attention to the preparation of university teachers. Interpretation of SD mainly depends on the teachers. Slovak economic faculties and universities focus on 
a preparation of university teachers for the practice in a new globalizing environment. Their task is to manage students so that they will be able to cope with many social and civilization changes arising as a consequence of globalization without threatening future generations. The courses of university education offered to the teachers by the Slovak technical and economic universities nowadays seem to be very supportive. Apart from that also some other forms of accredited education which is offered to the teachers at elementary and secondary levels should be also provided for university teachers. Thus, they would provide more complex preparation for fulfilling actual tasks in education. Focusing on sustainable development in education at economic universities is not connected only with an attempt to higher the quality of education but also to higher the quality of human life in a new globalizing world.

\section{Bibliographic references}

BOURN, D. 2003. Global perspectives in higher education: the contribution of development education [electronic version]. Available online: https://www.google.sk/search?q=BOURN\%2C+D.+GLOBAL+PERSPECTI VES+IN+HIGHER+EDUCATION\&oq=BOURN\%2C+D.+GLOBAL+PER SPECTIVES+IN+HIGHER+EDUCATION\&aqs=chrome..69i57.491j0j4\&so urceid $=$ chrome\&ie $=$ UTF- 8

BOURN, D. 2008. Education for sustainable development in the UK: Making the connections between the environment and development agendas. In Theory and Research in Education: July 2008, Vol. 6, N. 2, p. 193-206.

BUORN, D. (n.d.). 'Global Perspectives and Education for Sustainable Development for Lifelong Learning'. London: NIACE. Available online: www.niace.org.uk/lifelonglearninginquiry/docs/Doug-Bourn-Globalperspectives.pdf

DETR. 1998. Sustainable Development Education Panel.First Annual Report.London. Available online: http://www.tidegloballearning.net/sites/default/files/uploads/Sustainable_Dev elopment_Education_Panel_Annual_Report_1998.pdf

DfES. 2003. Sustainable Development Action Plan. London: DfES. Available online: https://www.gov.uk/browse/education/universities-highereducation

ESDGC. 2008. Education for Sustainable Development and Global Citizenship.A Common Understanding for Schools.Information Document No: 065/2008. Available online: http://gov.wales/docs/dcells/publications/081204commonunderstschoolsen.p df

EU. 2010. Závery Rady o internacionalizácii vysokoškolského vzdelávania. [online] Brusel. Retrieved from https://www.minedu.sk/data/att/2297.pdf. European Commission. 2013. Communication from the Commission to the European Parliament, the Council, the European Economic and Social Committee and the Committee of the Regions. Brussels, 11.7.2013 COM (2013) 499 final. Available online: http://eur-lex.europa.eu/legalcontent/EN/TXT/PDF/?uri=CELEX:52013DC0499\&from=SK 
HEFCE. 2005. Sustainable Development Action Plan - Consultation Document.London: HEFCE. Available online: http://webarchive.nationalarchives.gov.uk/20100202100434/http://www.hefc e.ac.uk/pubs/hefce/2005/05_01.

HORVATHOVA, B. 2013. Methods in Researching and Teaching LanguageLearning Strategies; 1. vyd. Nitra: ASPA, 88 p. ISBN 978-8089477-11-1.

Ministry of Education of the Slovak Republic. 2015. Pedagogickoorganizacne pokyny na skolsky rok 2015/2016. [online]. Available online: http://www.minedu.sk/data/att/8285.pdf

ISRAEL, R. 2013. What does it mean to be a global citizen. In Our Kingdom : power \& liberty in UK [online]. OpenDemocracy, 13 February 2013 Retrieved from http://www.opendemocracy.net/ourkingdom/ron-israel/whatdoes-it-mean-to-be-global-citizen

KOHUTOVA, V. 2016. Developing speaking in English language classroom. In: Teaching together, Learning together. Nitra: UKF, 2016, S. 52-59. ISBN 978-80-558-0974-8. Available online: http://www.klis.pf.ukf.sk/dokumenty/Publikacie/Zborník_SKA\%202016_fin al.pdf).

MALA, E. 2009. Jazykova a interkulturna dimenzia $\mathrm{v}$ procese internacionalizacie vysokoskolskeho vzdelavania. In: Ianua ad linguas hominesque reserata II. Paris: Asiatheque - Maison des langues du Monde, pp. 100-123. ISBN 978-2-91525596-6.

MINZP. (n.d.)Narodna strategia trvalo udrzatel'neho rozvoja Slovenskej republiky. Cast' I. pp. 1-33. Available online: http://www.minzp.sk/dokumenty/strategicke-dokumenty/

MOHAMEDBHAI, G. 2015. What role for higher education in sustainable development? University World News.09.January 2015.Issue No: 349. [cit. 2016-03-20]. Available online: http://www.universityworldnews.com/article.php?story=2015010819423121 3

OECD. 2003. The Definition and Selection of Key Competencies. Executive summary. Available online: http://www.oecd.org/pisa/35070367.pdf

OXFAM. 2006. Education for Global Citizenship: A guide for schools, 2015. OXFAM [cit. 2016-04 09]. Available online: file:///C:/Users/Admin/Downloads/education_for_global_citizenship_a_guide for schools.pdf

$\bar{R} E I \bar{D}$, E. 2013. Models of Intercultural Competences in Practice.International Journal of Language and Linguistics. Vol. 1, n. 2, pp. 44-53. ISSN 2330-0221.

SEA (Slovak Environment Agency). 2016. Ponuka vzdelávacích podujatí pre učitel'ov. Available online: http://www.sazp.sk/public/index/go.php?id=2070\&idl=2070\&idf=1068\&lang $=\mathrm{sk}$

United Nations.(n.d.) Decade of Education for Sustainable Development. 2005-2014. Available online: http://unesdoc.unesco.org/images/0014/001416/141629e.pdf 
UN-DESA. 2015. Sustainable Development. Knowledge Platform. Available online: https://sustainabledevelopment.un.org/post2016/summit

UNECE. 2005. Sustainable development - concept and action. Annual Report 2004-2005. Available online: http://www.unece.org/oes/nutshell/20042005/focus_sustainable_development.html

UNECE. 2009. Learning from each other. The EDUCE strategy for education for sustainable development. https://sustainabledevelopment.un.org/content/documents/798ece5.pdf

UNESCO. 2014. Global Citizenship Education.Preparing learners for the challenges of the twenty-first century. 44 p. ISBN 978-92-3-100019-5.

United Nations. (n.d).Sustainable development knowledge platform. Higher education sustainability initiative. In www Sustainability development knowlwdge platform. Available online: https://sustainabledevelopment.un.org/sdinaction/hesi

United Nations. Economic and Social Council. 2005. Strategy EEC UN for education for sustainable development. Vilnius [online]. Available online: https://www.unece.org/fileadmin/DAM/env/esd/strategytext/Slovak.pdf United Nations. EEC. 2005. Strategy for education on sustainable development. Available online: https://www.unece.org/fileadmin/DAM/env/esd/strategytext/Slovak.pdf.

Veselá, K. 2012. Teaching ESP in New Environments: CA-CLIL. Nitra: ASPA, 113 p. ISBN 978-80-89477-06-7.

282 Acknowledgement

,This work was supported by the Slovak Research and Development Agency under the contract No. APVV-15-0368“. Prax v centre odborovej didaktiky, odborová didaktika v Centre praktickej prípravy."

Mgr. Eva Svitačová, PhD.

Slovak University of Agriculture

Faculty of Economics and Management Department of Social Sciences

Tr. Andreja Hlinku 2, 94976 Nitra

Slovakia

eva.svitacova@uniag.sk and

Mgr. Elena Kováčiková, PhD.

Constantine the Philosopher University in Nitra

Faculty of Education, Department of Language Pedagogy and Intercultural

Studies

Drážovská 4, 94901 Nitra

Slovakia

ekovacikova@ukf.sk 